\title{
Reconstructing glacier-based climates of LGM Europe and Russia - Part 3: Comparison with previous climate reconstructions
}

\author{
R. Allen ${ }^{1, *}$, M. J. Siegert ${ }^{2}$, and A. J. Payne ${ }^{1}$ \\ ${ }^{1}$ School of Geographical Sciences, University of Bristol, University Road, Bristol, BS8 1SS, UK \\ ${ }^{2}$ School of GeoSciences, University of Edinburgh, Grant Institute, King's Buildings, West Mains Road, \\ Edinburgh, EH9 3JW, UK \\ *now at: Landmark Information Group, 5-7 Abbey Court, Eagle Way, Sowton, Exeter, EX2 7HY, UK
}

Received: 26 September 2007 - Published in Clim. Past Discuss.: 26 October 2007

Revised: 16 September 2008 - Accepted: 8 October 2008 - Published: 13 November 2008

\begin{abstract}
Understanding past climates using GCM models is critical to confidently predicting future climate change. Although previous analysis of GCM simulations have shown them to under calculate European glacial temperature anomalies (the difference between modern and glacial temperatures) such analyses have focused primarily on results from glacial simulations alone. Here we compare glacial maximum GCM results with the palaeoenvironment derived from glacier-climate modelling. The comparison confirms that GCM anomalies are not large enough, and that this is due to modern conditions that are modelled too cold and glacial temperatures that are too warm. The result is that GCM results, if applied to a glacier mass balance model, over predict the extent of glaciers today, and under calculate their extent at the last glacial (as depicted in glacial geological reconstructions). Effects such as seasonality and model parameterisation change the magnitude of the under calculation but still fail to match expected glacial conditions.
\end{abstract}

\section{Introduction}

Allen et al. (2007a, b) have demonstrated that glacialgeological evidence of Quaternary mountain glaciers can be used to reconstruct estimates of past climates through glacier-climate modelling. These studies focused on the Last Glacial Maximum $(\mathrm{LGM})\left(\sim 18000^{14} \mathrm{C}\right.$ yr BP) climate of Europe and Russia, and provide the first opportunity for LGM glacial-geological information (and associated palaeoclimate) outside of the large LGM ice sheets (e.g. Pollard and

Correspondence to: M. J. Siegert

(m.j.siegert@ed.ac.uk)
PMIP Participating Group, 2000) to be incorporated into the analysis of retrospective General Circulation Model (GCM) simulations of this continent. This is a timely development because previous analyses of GCM simulations of European LGM palaeoclimates have been primarily restricted to using pollen data (e.g. Kageyama et al., 2001; Jost et al., 2005). Furthermore, the use of glacier mass balance in the assessment of palaeoclimate provides a method of considering both temperature and precipitation variables simultaneously. Previous model-proxy analyses for Europe have only considered single climatic variables independently and not the plausibility of combined climate processes.

The Paleoclimate Model Intercomparison Project (PMIP) (Joussame and Taylor, 1995) was established to evaluate and improve understanding of climate changes calculated by GCM simulations of the Late Quaternary and Holocene. This project analysed snapshot simulations of the LGM and present day from 17 GCMs parameterised using pre-defined consistent boundary conditions for each time period. PMIP2 is the follow up project and is performing similar assessments on the next generation of GCMs. The PMIP2 project has yet to be completed; as such there is not currently a complete database of results available.

The aim of this paper is to develop our understanding of European LGM climate by presenting results from a suite of comparison analyses between the glacial-geological LGM climate reconstructions of Allen et al. (2007b), the pollen climate reconstructions of Peyron et al. (1998) and Tarasov et al. (1999), and the HadCM3 simulation from PMIP2. The result is a quantitative assessment of the variability between palaeoclimate scenarios of LGM Europe, and an appreciation of the utility of glacial reconstructions in understanding past climates. A glossary of all acronyms used in this paper can be found in Appendix A.

Published by Copernicus Publications on behalf of the European Geosciences Union. 
Table 1. Regional HadCM3, pollen, (Peyron et al., 1998; Tarasov et al., 1999), and glacial-geological LGM temperature anomalies (Allen et al., 2007b) constrained by HadCM3 or pollen (Peyron et al., 1998; Tarasov et al., 1999) precipitation anomalies. The North of Alps climate signal is based on results from the Vosges Mountains, Black Forest, and Massif Central. The Mediterranean Basin climate signal is based on results from Iberian, Corsican, Southern Italian, and Adriatic Coast sites. The Eastern European climate signal is based on results from the Bulgarian and Romanian sites. The Eastern Black Sea climate signal is based on results from the Turkish, Armenian and Caucasus Mountain sites. Location of sites can be found in Fig. 1.

\begin{tabular}{lllll}
\hline & North of Alps & Mediterranean Basin & Eastern Europe & Eastern Black Sea \\
\hline Pollen & -12.0 & -9.0 & -15.0 & -8.5 \\
HadCM3 & -7.5 & -6.5 & -9.0 & -11.0 \\
Glacial-Geological (HadCM3) & -14.0 & -12.0 & -9.0 & -11.0 \\
Glacial-Geological (Pollen) & -16.0 & -14.5 & -10.0 & -13.5 \\
\hline
\end{tabular}

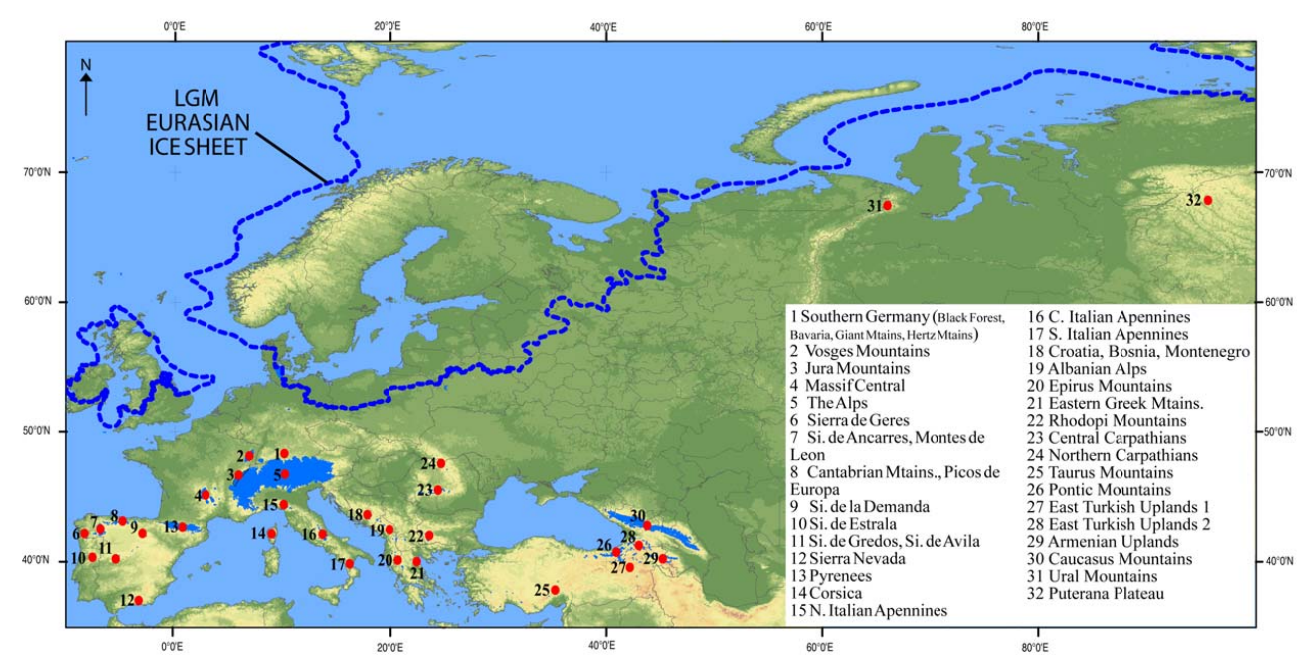

Fig. 1. Location of Quaternary glacial-geological evidence in Europe and Russia (adapted from Ehlers and Gibbard, 2004a).

\section{Comparison of General Circulation Model and proxy palaeoclimate reconstructions}

When comparing palaeoclimate reconstructions from proxy and model sources, it is usually assumed that they are directly compatible and discrepancies that currently exist between the different data sources relate to methodological shortcomings or a current lack of knowledge. It is furthermore assumed that climate reconstructions from different data sources will converge in the future as methodologies and knowledge improves. However, the diverse origins, reconstruction methods used, and final presentation of model and proxy results may prevent convergence, as illustrated in the following three examples:

1. GCMs resolve a climate at a relatively coarse scale, typically $\sim 300 \mathrm{~km}$ (Jost et al., 2005), and are not able to simulate local factors, such as topography, that have a significant influence on local-scale climate and are inherently reflected in proxy records. For example, the average altitude of the Tibetan Plateau is $\sim 5000 \mathrm{~m}$ a.s.l.
(Owen and Benn, 2005) yet the highest altitude for this region in a model used by Mark et al. (2005) was less than $4000 \mathrm{~m}$ a.s.l.

2. Plants (and therefore fossilised pollen records) will most reliably reflect "bioclimatic" variables (e.g. temperature of coldest month, growing degree days, or seasonal distribution of precipitation) that influence the growth and life cycle of the plant rather than "traditional" climate variables of mean annual temperature or annual precipitation (Prentice et al., 1992).

3. The mass balance of mountain glaciers is primarily controlled by winter accumulation and summer ablation (Porter 1977). The LGM climate reconstructions from glacial-geological evidence of Allen et al. (2007b) were not able to involve changes in seasonality owing to the simplicity of the glacier-climate model used. 
Despite these potential limitations comparison analyses remain useful. There is currently no viable alternative to the use of proxy data for assessing model results; the increasing production of proxy datasets constructed using the guidelines of Kohfeld and Harrison (2000) and Harrison (2003) will help to ensure that the compatibility between model and proxy datasets is maximised. Comparison analyses can qualitatively test the reliability of regional-scale trends determined by models (e.g. Kageyama et al., 2001; Kageyama et al., 2005), assess the relative contribution of specific climate processes to model climate and ecosystems predictions (e.g. Harrison and Prentice, 2003), and create a benchmark against which changes in model structure can be tested (e.g. Jost et al., 2005; Kageyama et al., 2005). The comparison of different proxy datasets is a good method of testing the robustness of regional trends present in individual proxy reconstructions (e.g. Farrera et al., 1999).

\section{Glaciological, palynological and HadCM3 LGM cli- mate reconstructions}

A brief overview of the three different LGM climate reconstructions used in the comparison analyses presented in this paper is provided in this section. The LGM precipitation/temperature dataset of Allen et al. (2007b) was derived from a glacier-climate model constrained by reconstructions of European LGM glaciers described in Ehlers and Gibbard (2004) (Fig. 1) using the principles of equilibrium in the glacier-climate system at zero surface mass balance. Annual LGM climate anomalies were reconstructed from a present day climate baseline described by the CRU2.0 $\sim 20 \mathrm{~km}$ resolution climate dataset (New et al., 2002) which had been verified against the present day cryosphere of Europe (Allen et al., 2007a). The model assumes that the glacier extents in Ehlers and Gibbard (2004) are correct, and that their extents were reached at the same time. Neither assumptions are likely to be strictly true, however. In several instances the timing of maximum glacial extent has been shown to vary, and there is often considerable debate still as to the size of even large ice masses across Europe during the last glacial. We defend the approach, however, as it utilises information from a recognised source, which can easily be modified when new data are available. Hence, this paper should be regarded as a necessary first step in the use of such modelling.

The LGM palaeoclimate reconstructions of Europe and Russia by Peyron et al. (1998) and Tarasov et al. (1999) were derived from fossil pollen records (Fig. 1, p. 190, Peyron et al., 1998 and Table 1, p. 230, Tarasov et al., 1999) dated to $18000 \pm 20000^{14} \mathrm{C}$ yr BP. Plant-climate relationships were established using an objective inverse method based on plant functional types (PFT) (Prentice et al., 1996) which are broad classes of plants that have identifiable characteristics (e.g. leaf morphology or phenology) and distinctive climatic requirements (e.g. cold tolerance or moisture require- ments). Modern day pollen assemblages are used to assign individual plant taxa to a PFT, which can then be calibrated in terms of climate. Comparison of PFT distributions from a fossil pollen assemblage and modern analogue assemblages are used to infer palaeoclimatic conditions. An argument, similar to that made above concerning chronology, can be made about pollen-based climate reconstructions. Only half of the pollen data from Europe have been dated, and several sites have a chronology that is equivocal. Thus, the situation in which proxy data and glaciers can be used to infer past climates is not without potentially significant timing issues. One such issue could be the misinterpretation of Heinrich event pollen assemblages as from the LGM. In some places, the climate from pollen data during Heinrich events has been shown to be cooler than at the LGM (e.g. Turon et al., 2003). If such data were mis-interpretated as being from the LGM, it might lead to an expectation that the LGM was colder than it actually was.

HadCM3 is a coupled atmosphere-ocean model developed at the Hadley Centre (Gordon et al., 2000). The atmosphere is simulated using the HadAM3 model which has a horizontal resolution of $2.5^{\circ}$ latitude by $3.75^{\circ}$ longitude, 19 vertical levels, and runs on a $30 \mathrm{~min}$ time step (Pope et al., 2000). The radiative effects of $\mathrm{CO}_{2}$, water vapour, ozone, and minor greenhouse gases are explicitly represented in a radiation scheme using 6 and 8 spectral bands for shortwave and longwave radiation, respectively. A cloud water variable is used to simulate large-scale precipitation and cloud distribution. The land surface scheme calculates surface albedo, soil moisture freezing and melting, soil runoff, soil drainage, surface runoff, and evaporation (Gordon et al., 2000). The ocean model has a horizontal resolution of $1.25^{\circ} \times 1.25^{\circ}$ with 20 vertical levels. Both horizontal and vertical mixing of tracers within the ocean is considered in the model, and sea ice is calculated from a simple thermodynamic scheme. The atmosphere and ocean models are coupled once per day with conservation of heat and water fluxes. PMIP2 use the following key parameters: for $0 \mathrm{k}$ simulations, orbital insolation patterns set at $1950 \mathrm{AD}$ (Berger and Loutre, 1991) and atmospheric greenhouse gas concentrations $280 \mathrm{ppm} \mathrm{CO}_{2}, 760 \mathrm{ppbCH}_{4}$, and $270 \mathrm{ppb} \mathrm{N}_{2} \mathrm{O}$ (pre-industrial levels $\sim 1750 \mathrm{AD}$ ); for $21 \mathrm{k}$ simulations orbital insolation patterns set to $21000 \mathrm{yr} \mathrm{BP}$ (Berger and Loutre, 1991), atmospheric greenhouse gas concentrations of $185 \mathrm{ppm} \mathrm{CO}_{2}, 350 \mathrm{ppbCH}_{4}$, and $200 \mathrm{ppb} \mathrm{N}_{2} \mathrm{O}$, and LGM cryosphere defined by the ICE-5G ice sheet reconstructions (Peltier, 2004). Full documentation of the PMIP2 framework and HadCM3 PMIP2 simulation can be found online at http://pmip2.1sce.ipsl.fr/ LGM climate anomalies are the difference between the $21 \mathrm{k}$ and $0 \mathrm{k}$ simulations. The calendar date of $\sim 21000 \mathrm{yr}$ BP used by the modelling community to constrain LGM simulations is equivalent to the radiocarbon date of $\sim 18000^{14} \mathrm{C}$ yr BP (Fairbanks et al., 2005). 
Western Europe

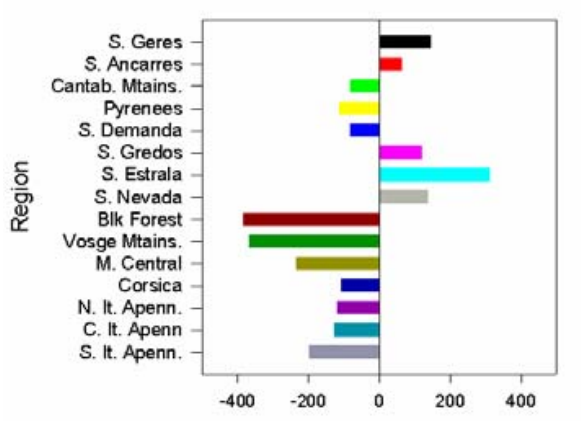

HADCM3 Annual LGM Precipitation Anomaly (mm)

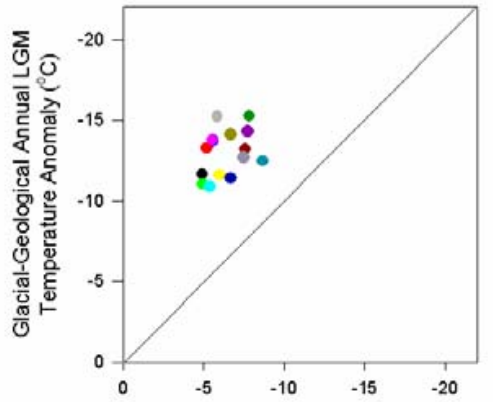

HADCM3 Annual LGM Temperature Anomaly $\left({ }^{\circ} \mathrm{C}\right)$

Eastern Europe and Black Sea Region
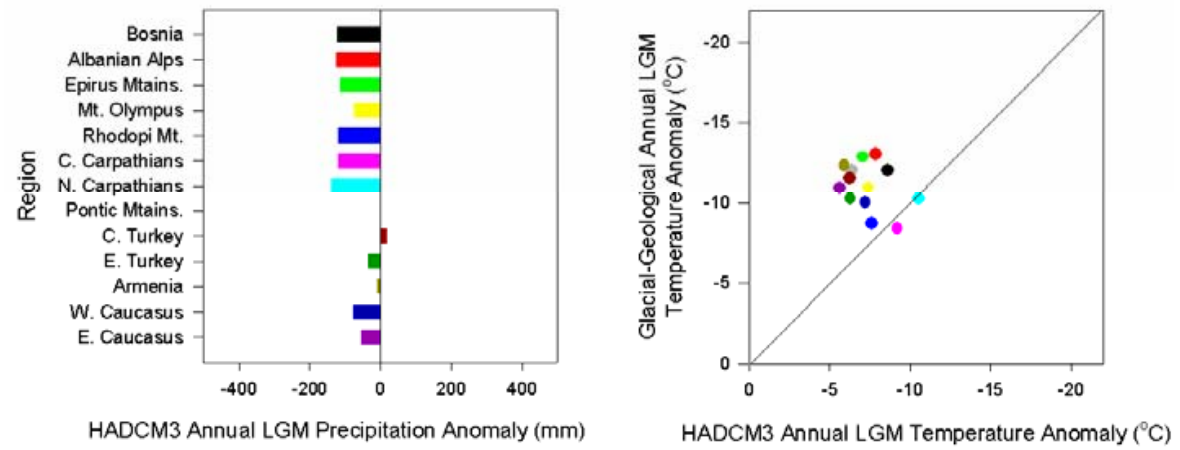

Puterana Plateau and Ural Mountains
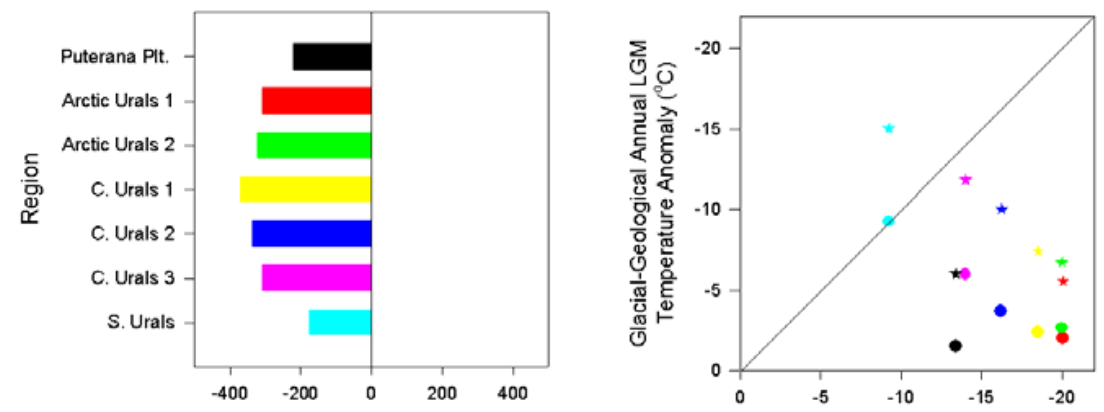

HADCM3 Annual LGM Precipitation Anomaly ( $\mathrm{mm}$ )

Fig. 2. Comparisons of HadCM3 and glacial-geological LGM climate anomalies (Allen et al., 2007b). HadCM3 precipitation anomalies for each region are shown in the left hand graphs and the colour of these bars can be used to identify the regional temperature anomalies in the right hand graphs. Owing to uncertainty in the LGM glacial extent in the Ural Mountains and Puterana Plateau (see Allen et al., 2007b for a full explanation) the temperature anomalies from the minimum and maximum glacial coverage are plotted (as the circles and stars, respectively). The location of each region can be found in Fig. 1. Note the axes in the right hand graphs have been inverted, the diagonal line represents the 1:1 line; any data point plotting above the 1:1 line indicates the glacial-geological temperature anomaly is larger than the HadCM3 temperature anomaly for that region and vice versa for data points plotting below the 1:1 line.

\section{Initial comparison}

The initial assessment consisted of two parts, first a comparison between HadCM3 and pollen LGM climate anomalies with those reconstructed directly by a mass balance model (tuned to glacial-geological evidence) and, second, a comparison of the LGM glaciers calculated using inputs from
HadCM3 and pollen LGM climates to a mass balance model with the LGM glacier reconstructions of Ehlers and Gibbard (2004).

LGM climate reconstructions from glacial-geological evidence were constructed as a range of plausible LGM climate reconstructions (Allen et al., 2007b). In contrast GCM and pollen reconstructions create a single optimum LGM 
Western Europe
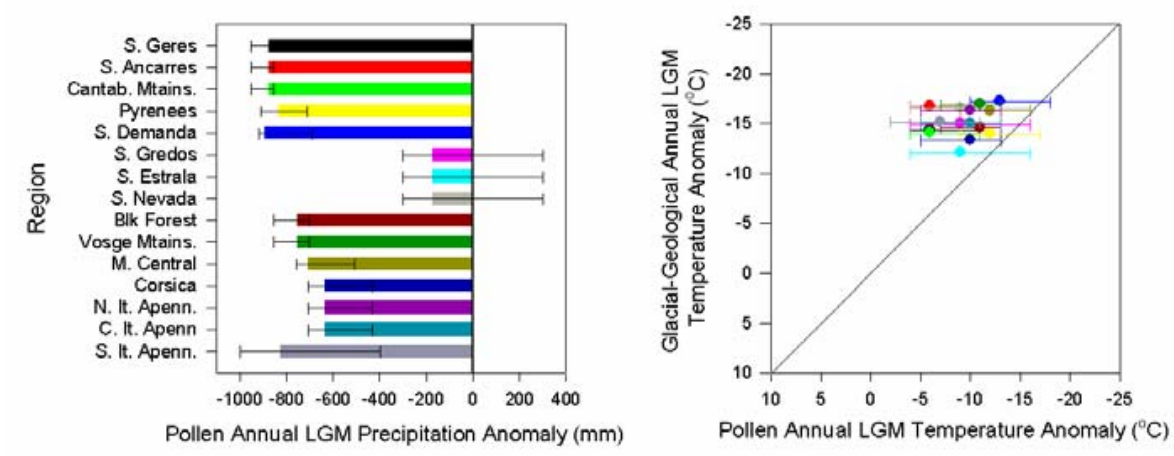

Eastern Europe and Black Sea Region
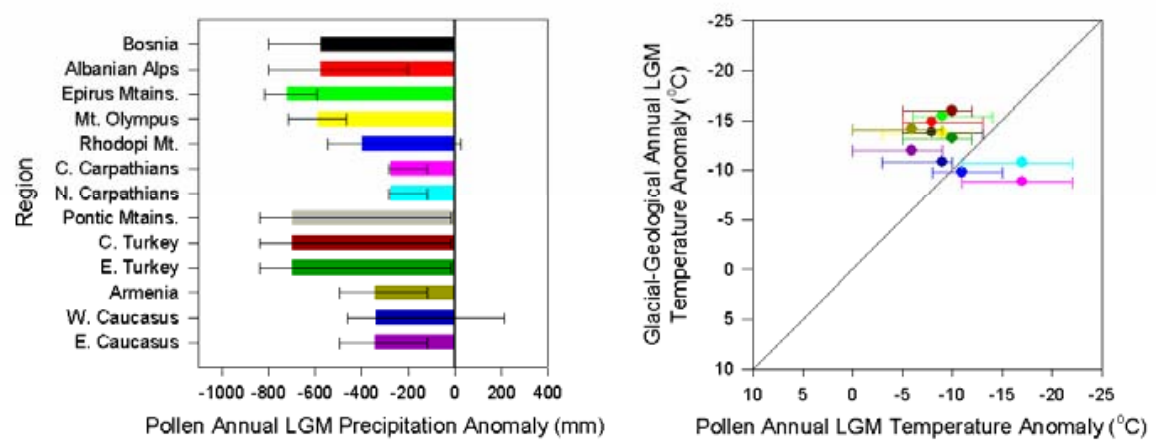

Puterana Plateau and Ural Mountains
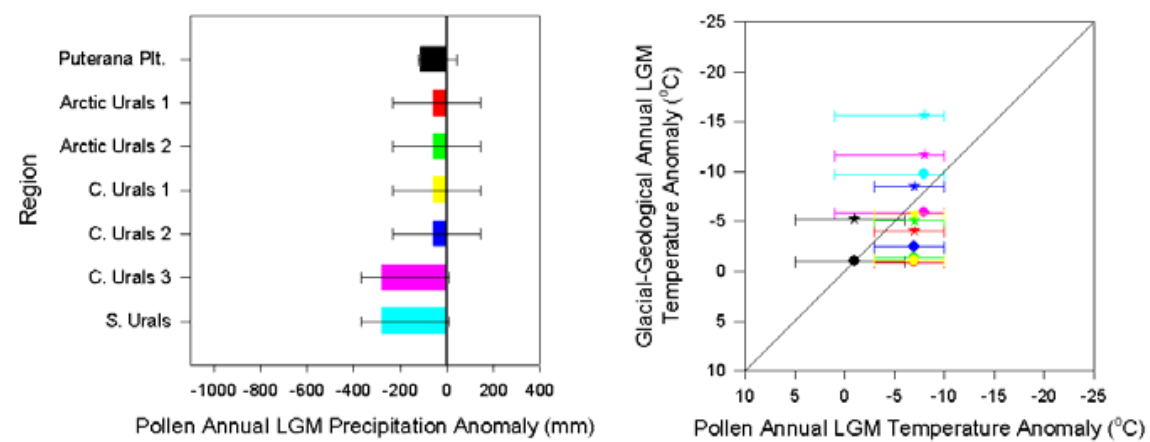

Fig. 3. Comparisons of pollen (Peyron et al., 1998; Tarasov et al., 1999) and glacial-geological LGM climate anomalies (Allen et al., 2007b). Pollen precipitation anomalies for each region are shown in the left hand graphs and the colour of these bars can be used to identify the regional temperature anomalies in the right hand graphs Pollen climate anomalies are reconstructed as a most plausible reconstruction accompanied by an error bar. Comparison to the glacial-geological data was made using the optimum reconstruction. Owing to uncertainty in the LGM glacial extent in the Ural Mountains and Puterana Plateau (see Allen et al., 2007b for a full explanation) the temperature anomalies from the minimum and maximum glacial coverage are plotted (as the circles and stars, respectively). The location of each region can be found in Fig. 1. Note the axes in the right hand graphs have been inverted, the diagonal line is the 1:1 line; any data point plotting above the 1:1 line indicates the glacial-geological temperature anomaly is larger than the pollen temperature anomaly for that region and vice versa for data points plotting below the 1:1 line.

climate scenario. For the initial climate comparison it was assumed that the precipitation anomalies for the GCM and pollen data were correct. Corresponding glacial-geological temperature anomalies were derived from a regression curve plotted through the glacial-geological climate reconstruction
(Allen, 2006). This ensured that the glacial-geological temperature anomalies used in this paper were interpolated from the dataset of Allen et al. (2007b). The extent of LGM glaciers that would result from HadCM3 and pollen LGM climate anomalies were calculated using the glacier-climate 
model of Allen et al. (2007a, b). This required HadCM3 and pollen data to be transformed to make them compatible with the model. HadCM3 monthly mean air temperature, monthly precipitation, and elevation data from the $0 \mathrm{k}$ and $21 \mathrm{k}$ simulations were extrapolated onto a grid with the same resolution and latitude-longitude attributes as the CRU2.0 climate data (New et al., 2002) used by Allen et al. (2007b). The downscaled climate for each $\sim 20 \mathrm{~km}$ grid cell was calculated from the nearest four nodes in HadCM3 using spherical geometry:

$D=\operatorname{arcos}\left(\sin \left(L_{1}\right) \times \sin \left(L_{2}\right)+\cos \left(L_{1}\right) \times \cos \left(L_{2}\right) \times \cos \left(G_{2}-G_{1}\right)\right)$

where $D$ is the distance between two points, $L_{1}$ and $L_{2}$ and $G_{1}$ and $G_{2}$ are the latitude and longitude, respectively of the two points being considered. A weighting system was used to reflect the distance between the contributing HadCM3 nodes and the CRU2.0 grid cell with the closest HadCM3 node receiving the largest weighting. It was assumed that the extrapolated climate is representative of the topography onto which it has been applied. The pollen site closest to each glaciated region was used to drive the model and it was assumed that the LGM climate anomalies for each pollen site were spatially uniform across the glaciated region to which they were applied. The transformed HadCM3 and pollen LGM climate anomalies were applied to the CRU2.0 climate dataset, which was then downscaled (using modern lapse rates) onto the reconstructed LGM glacier profiles modelled in Allen et al. (2007b). The downscaling methodology is described in Allen et al. (2007a, b). These input data were used in a mass balance model to calculate key glaciological variables such as proportions of glacial coverage, equilibrium line altitudes (ELA), accumulation area ratios (AAR), and cumulative mass balances.

\subsection{Annual temperature and precipitation anomalies}

In this section precipitation anomalies are presented in absolute terms $(\mathrm{mm})$ plus a corresponding change from the CRU2.0 dataset (New et al., 2002). In Western Europe HadCM3 precipitation anomalies range from $-385 \mathrm{~mm}$ to $+320 \mathrm{~mm}(-40 \%$ to $+23 \%)$. Under these precipitation regimes annual temperature anomalies from the glacialgeological dataset are between $3.7^{\circ} \mathrm{C}$ and $9.3^{\circ} \mathrm{C}$ larger than the corresponding HadCM3 estimates (Fig. 2). In Eastern Europe and the Eastern Black Sea region HadCM3 annual precipitation anomalies range from $-139 \mathrm{~mm}$ to $+75 \mathrm{~mm}$ $(-16 \%$ to $+3 \%)$; glacial-geological temperature anomalies are between $1.0^{\circ} \mathrm{C}$ and $6.4^{\circ} \mathrm{C}$ larger than HadCM3 estimates, except in the Romanian Carpathians where there is less than $1{ }^{\circ} \mathrm{C}$ difference (Fig. 2). In Russia HadCM3 precipitation anomalies range from $-369 \mathrm{~mm}$ to $-77 \mathrm{~mm}$ ( $-70 \%$ to $-41 \%$ ), and HadCM3 temperature anomalies are between $7.4^{\circ} \mathrm{C}$ and $14.5^{\circ} \mathrm{C}$ larger than those corresponding to the largest mountain glaciers reconstructed by Allen et al. (2007b) (Fig. 2). Precipitation anomalies in Western Europe reconstructed from pollen range from $-878 \mathrm{~mm}$ to
$-173 \mathrm{~mm}(-110 \%$ to $-13 \%)$ (Peyron et al., 1998). Glacialgeological temperature anomalies are between $3.1^{\circ} \mathrm{C}$ and $10.8^{\circ} \mathrm{C}$ larger than optimum pollen temperature anomalies (Fig. 3). Across Eastern Europe and Eastern Black Sea pollen precipitation anomalies range between $-718 \mathrm{~mm}$ and $-274 \mathrm{~mm}(-119 \%$ to $-27 \%)$. Glacial-geological temperature anomalies are larger than optimum pollen temperature anomalies by between $1.8^{\circ} \mathrm{C}$ and $8.1^{\circ} \mathrm{C}$ (Fig. 3), except in the Rhodopi and Carpathians Mountains where optimum pollen temperature anomalies are $1.4^{\circ} \mathrm{C}$ to $8.2^{\circ} \mathrm{C}$ larger than glacial-geological estimates (Fig. 3). In Russia, pollen precipitation anomalies range from $-277 \mathrm{~mm}$ to $-58 \mathrm{~mm}$ $(-50 \%$ to $-9 \%)$ and the corresponding pollen and glacialgeological temperature anomalies are reasonably well correlated (Fig. 3).

Despite the range of LGM precipitation and temperature anomalies reconstructed by the three datasets there are consistent relative trends in the spatial distribution of the climate anomalies. Glacial-geological temperature anomalies (constrained using either HadCM3 or pollen precipitation anomalies) are larger north of the Pyrenees-Alps line than across the Mediterranean Basin. This distribution is similar to the pollen temperature anomalies of Peyron et al. (1998) which are $3^{\circ} \mathrm{C}$ larger north of the Pyrenees-Alps line (Table 1). The smallest constrained glacial-geological temperature anomalies are reconstructed in Eastern Europe; however this trend is not present in either HadCM3 or pollen temperature reconstructions (Table 1).

\subsection{Calculations of the European LGM glacier extent from HadCM3 and pollen LGM climate anomalies}

LGM glaciers calculated by the mass balance model using HadCM3 LGM climate anomalies in Western Europe are smaller than glaciers reconstructed from glacial-geological evidence (Ehlers and Gibbard, 2004). Across the Mediterranean and Pyrenees ELA estimates are between $380 \mathrm{~m}$ and $825 \mathrm{~m}$ higher than ELAs reconstructed by Allen et al. (2007b) (Fig. 4). North of the Alps, HadCM3 LGM climate anomalies are not large enough to lower the LGM ELA below the maximum altitude of the Black Forest and Vosges Mountains. Glaciers calculated in the Massif Central are confined to the highest peaks rather than the large ice-cap style glaciation described in Ehlers and Gibbard (2004). HadCM3 climate anomalies successfully allow LGM glaciers to be calculated in all mountain ranges across Eastern Europe and Eastern Black Sea, but ELAs are all higher than the ELAs reconstructed by Allen et al. (2007b) (Fig. 4) and are not sufficient to sustain LGM glaciers described in the INQUA dataset (Ehlers and Gibbard, 2004). These differences in cryospheric calculations are achieved despite relatively close agreement between the LGM annual climate anomalies reconstructed by HadCM3 and glacialgeological evidence in these regions, and reflect differences in the reconstructed seasonality of the different datasets, 


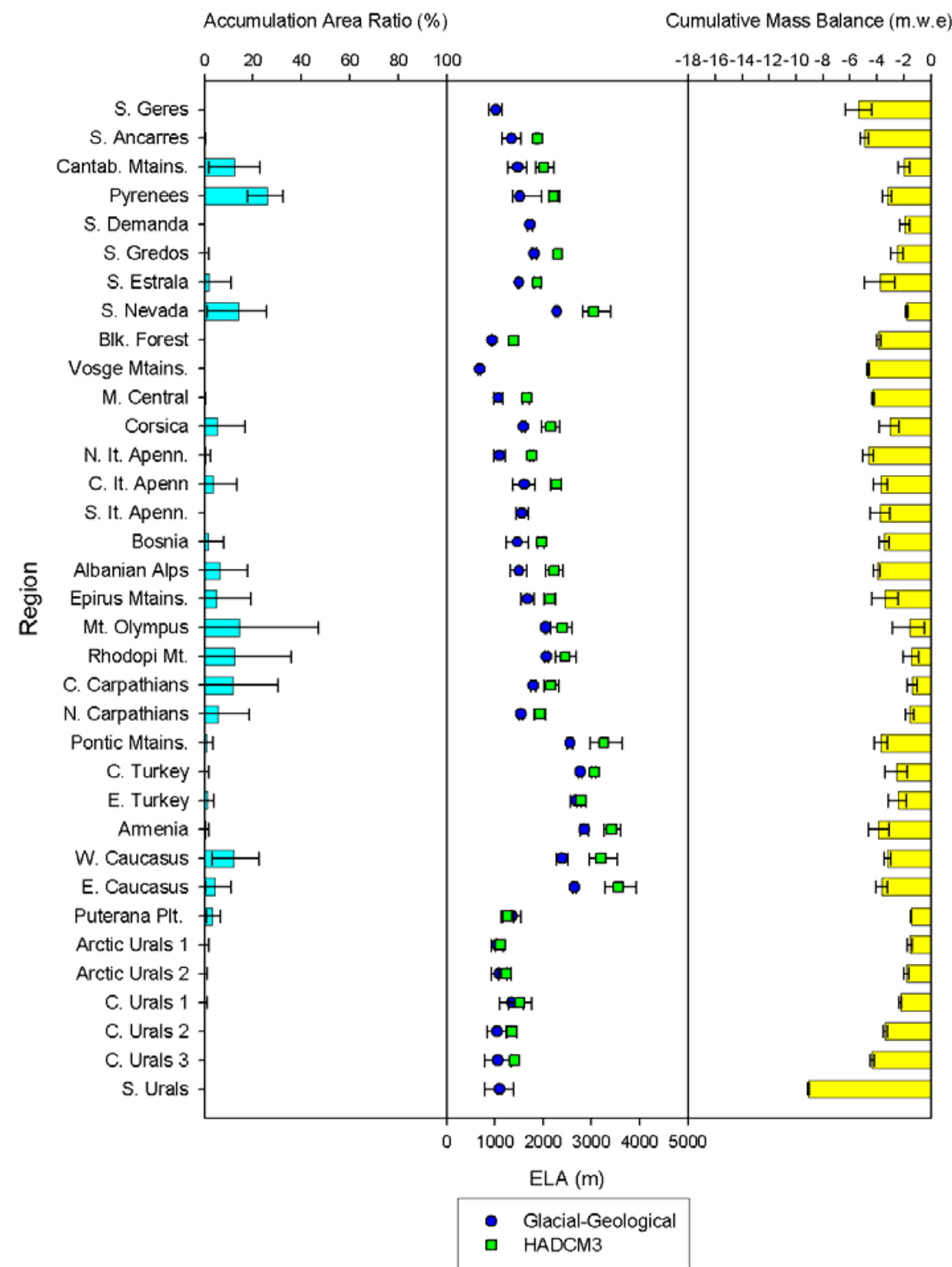

Fig. 4. HadCM3 LGM climate anomaly predictions of AAR, ELA, and cumulative mass balance for regions glaciated during the LGM (the location of regions can be found in Fig. 1). The AAR and cumulative mass balance results are calculated assuming that the fixed dimensions of the INQUA LGM glacier reconstructions (Ehlers and Gibbard, 2004) are correct. ELA predictions are plotted alongside the ELA estimates from the Allen et al. (2007b) (labelled as glacial-geological). The range in results for each region (represented by minimum and maximum error bars) is caused by the suite of lapse rate combinations used to downscale the input climate onto the model glacier surface simulating different annual mass balance profiles and therefore different glaciological results.

which is investigated further below. In Russia HadCM3 LGM climate anomalies yield only small LGM glaciers from the mass balance model (Fig. 4). Pollen LGM climate anomalies, when input to the mass balance model, result in glacial extents similar to those using HadCM3 in the majority of regions. For example, the largest glaciers are simulated in the Pyrenees, but the ELA is $575 \mathrm{~m}$ higher than those reconstructed by Allen et al. (2007b) (Fig. 5). The exception to this trend is in the Romanian Carpathians and Rhodopi Mountains where pollen temperature anomalies are very large (Fig. 3), which lead to glaciers calculated far larger than described in the glacial-geological evidence (Ehlers and Gibbard, 2004) (Fig. 5). Pollen LGM climate anomalies lead to large glaciers calculated in the Arctic Urals (Fig. 5). These 


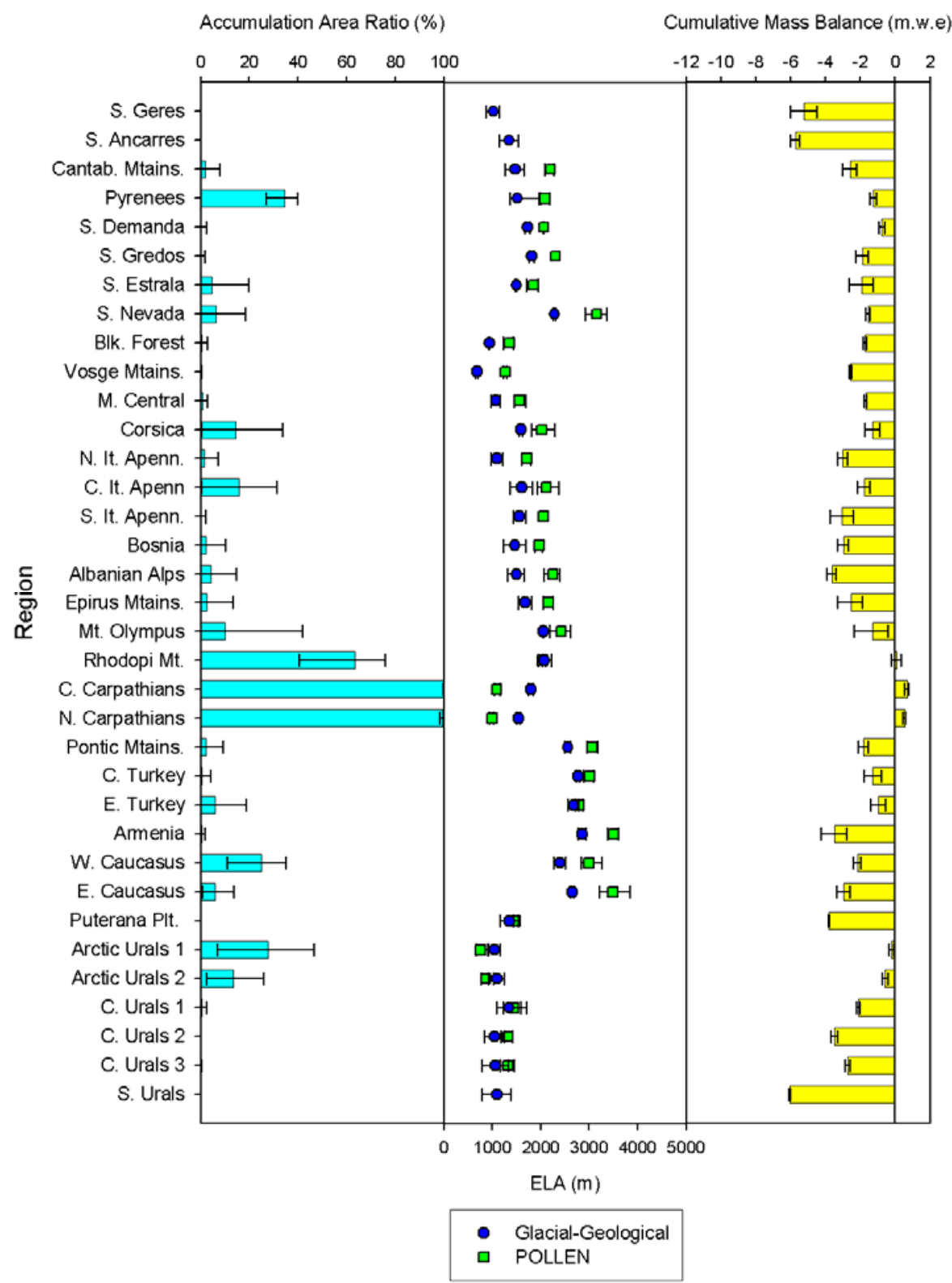

Fig. 5. Pollen LGM climate anomaly (Peyron et al., 1998; Tarasov et al., 1999) predictions of AAR, ELA, and cumulative mass balance for regions glaciated during the LGM (the location of regions can be found in Fig. 1). The AAR and cumulative mass balance results are calculated assuming that the fixed dimensions of the INQUA LGM glacier reconstructions (Ehlers and Gibbard, 2004) are correct. ELA predictions are plotted alongside the ELA estimates from the Allen et al. (2007b) (labelled as glacial-geological). The range in results for each region (represented by minimum and maximum error bars) is caused by the suite of lapse rate combinations used to downscale the input climate onto the model glacier surface simulating different annual mass balance profiles and therefore different glaciological results.

results must be treated as a maximum because only the annual climate variables were used; in the Urals, pollen summer temperature anomalies range from $0^{\circ} \mathrm{C}$ to $3^{\circ} \mathrm{C}$ colder, compared to $5^{\circ} \mathrm{C}$ to $8^{\circ} \mathrm{C}$ colder for the annual temperature anomaly. No LGM glaciers were simulated over the Puterana Plateau owing to the very small annual temperature anomaly.
The different seasonality of the LGM climate anomalies reconstructed by the three datasets has a significant effect on calculated LGM glacier extents. For example, LGM temperature anomalies in the glacial-geological dataset (Allen et al., 2007b) were applied uniformly throughout the year; in contrast HadCM3 explicitly simulates changes in seasonality. HadCM3 temperature anomalies in Russia range from $-17.0^{\circ} \mathrm{C}$ to $-30.0^{\circ} \mathrm{C}$ in January compared to $-3.0^{\circ} \mathrm{C}$ to 
$-5.6^{\circ} \mathrm{C}$ in July. These temperature anomalies create an absolute model climate with positive air temperatures during July and August but winter temperatures as low as $-55^{\circ} \mathrm{C}$, (compared to winter temperatures of $-30^{\circ} \mathrm{C}$ and $-40^{\circ} \mathrm{C}$ for glacial-geological and pollen reconstructions, respectively). Coupled to the low annual precipitation totals the short period of summer ablation is sufficient to limit glaciers to the very highest reaches of the polar Ural Mountains (Fig. 4), despite substantially larger annual temperature anomalies compared to the glacial-geological reconstructions of Allen et al. (2007b) (Fig. 2).

\subsection{Discussion of initial comparison}

The pollen LGM climate does not allow the mass balance model to simulate glacial conditions compatible with the glacial-geological evidence (Ehlers and Gibbard, 2004). One explanation is that pollen records reconstruct both excessively large precipitation anomalies, which restrict winter accumulation, and temperature anomalies that are not large enough to limit summer ablation sufficiently to sustain larger glaciers. This supports laboratory experiments which have demonstrated how low atmospheric $\mathrm{CO}_{2}$ concentrations can enhance plant sensitivity to drought stress and reduces plant water use efficiency, therefore the expansion of drought tolerant species (commonly reconstructed at the LGM) will reflect a biosphere response to both increased aridity and lower atmospheric $\mathrm{CO}_{2}$ (Cowling and Sykes, 1999). Temperature anomalies (of $-17^{\circ} \mathrm{C}$ ) reconstructed from the fossil pollen records at Korman and Anetovka II sites in the Ukraine are between -4 and $-11^{\circ} \mathrm{C}$ larger than any other pollen temperature anomaly in Western Europe. The large glaciers calculated using the pollen climate anomalies in the Romanian Carpathians (Fig. 5) are incompatible with the glacialgeological evidence and supports the opinion of Kislov et al. (2002), who, in a re-analysis of these sites, concluded that the pollen assemblage may be unreliable owing to vegetational disturbances.

Allen et al. (2007b) concluded that the Arctic Urals and Puterana Plateau were most likely to have been glaciated by small mountain-glaciers during the LGM; and potentially required only relatively small changes $\left(\sim-5^{\circ} \mathrm{C}\right)$ to the present day climate. These results are compatible with the pollen reconstructions for the region which range from $-1^{\circ} \mathrm{C}$ to $-10^{\circ} \mathrm{C}$ (Tarasov et al., 1999) (Fig. 3). HadCM3 LGM annual temperature anomalies for the Arctic Urals and Puterana Plateau are larger than glacial-geological based reconstructions (Allen et al., 2007b) (Fig. 3) but calculated glaciation is limited to small mountain glaciers in the upper reaches of both regions (Fig. 4).

Despite the limitations of the glacial-geological (Allen et al., 2007b) and pollen (discussed above) climate reconstructions, the combined effect of (1) these two proxies reconstructing LGM temperature anomalies larger than HadCM3 estimates and (2) the limited ability of HadCM3 LGM cli- mate anomalies to calculate LGM glaciers, suggest that European temperature anomalies from HadCM3, and other GCMs (e.g. Allen, 2006; Kageyama et al., 2001), are an under-calculation, which is investigated further in Sect. 5 .

\section{Exploring the discrepancy between HadCM3 and glacial-geological LGM climate reconstructions}

It was concluded in Sect. 4 that HadCM3 LGM temperature anomalies were too small and unable to sustain LGM glaciers of the size reconstructed from glacial-geological evidence (Ehlers and Gibbard, 2004). The remainder of this paper presents results from three model simulations designed to investigate the validity of this conclusion.

\subsection{LGM climate "correction factors"}

The correction required for either HadCM3 LGM temperature or precipitation anomalies to simulate steady state glaciers compatible with the LGM glacial-geological evidence (Ehlers and Gibbard, 2004) was established by the mass balance model. An iterative procedure was used to determine the correction in temperature (or precipitation) anomalies required to simulate zero mass balance steady state conditions over the LGM glacier profiles modelled by Allen et al. (2007b). The first iteration was the original simulation presented in Sect. 4, following this a $0.1^{\circ} \mathrm{C}$ correction was applied to the temperature (or $10 \mathrm{~mm}$ precipitation) and the simulation repeated until zero mass balance was simulated on the glacier surface. Correction factors were applied uniformly to each month to ensure the seasonal pattern of climate change calculated by HadCM3 was maintained. It is acknowledged that the "corrected" HadCM3 LGM climate anomalies are divorced from the physical calculations of the original $0 \mathrm{k}$ and $21 \mathrm{k}$ simulations; however, the results can be used to infer the first-order cause of the discrepancy between HadCM3 and glacial-geological LGM climate calculations.

Average temperature anomaly correction factors range from $-5.0^{\circ} \mathrm{C}$ to $-7.5^{\circ} \mathrm{C}$ in Western Europe, $-3.5^{\circ} \mathrm{C}$ to $-6.5^{\circ} \mathrm{C}$ in Eastern Europe, and $-5.5^{\circ} \mathrm{C}$ to $-8.5^{\circ} \mathrm{C}$ in the Eastern Black Sea, producing adjusted temperature anomalies ranging from $-9.0^{\circ} \mathrm{C}$ to $-15.0^{\circ} \mathrm{C},-11.0^{\circ} \mathrm{C}$ to $-16.5^{\circ} \mathrm{C}$, and $-12.0^{\circ} \mathrm{C}$ to $-14.5^{\circ} \mathrm{C}$ in these three regions, respectively (Fig. 6). In Western Europe and Eastern Black Sea, the corrected HadCM3 temperature anomalies are in closer agreement with the glacial-geological values of Allen et al. (2007b) (Fig. 6 and Table 2). In Eastern Europe, the correction factors increase the discrepancy between the two LGM climate datasets (Fig. 6 and Table 2), reflecting the different seasonality of the glacial-geological and HadCM3 LGM temperature anomalies. HadCM3 winter temperature anomalies are larger than summer temperature anomalies in this region. 
Western Europe

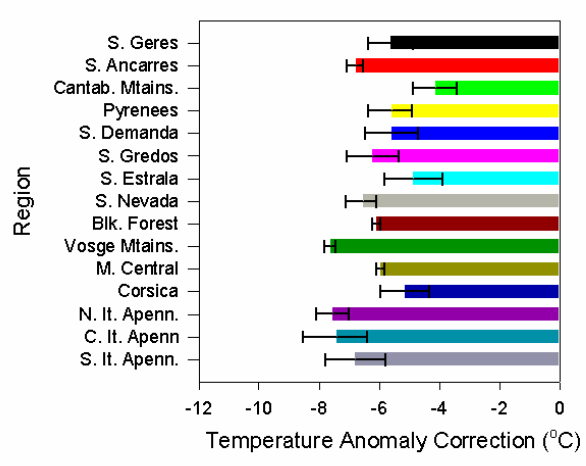

Eastern Europe and Black Sea Region

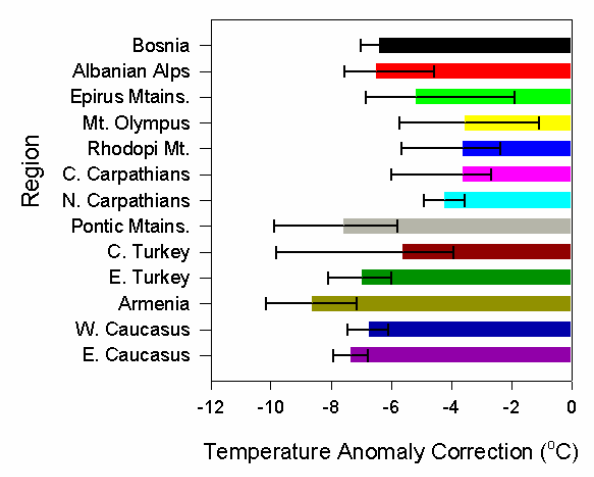

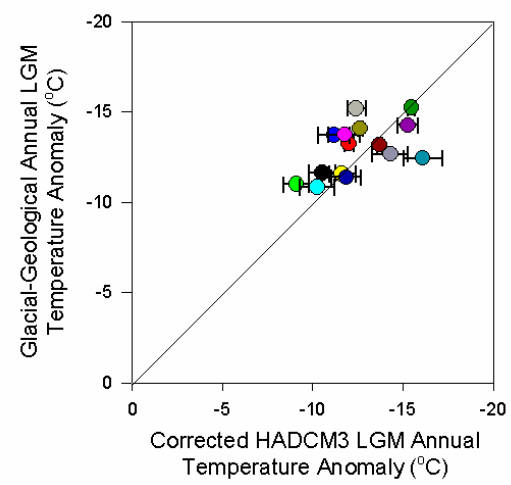

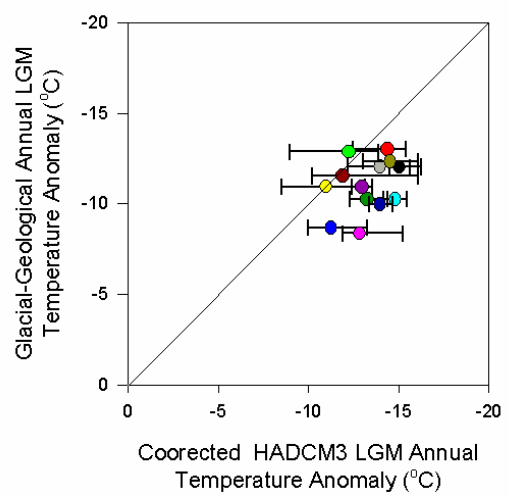

Fig. 6. Comparisons of "corrected" HadCM3 and glacial-geological LGM temperature anomalies from Allen et al. (2007b). The "correction" factor is shown in the left hand graph and the colour of these bars can be used to identify the temperature anomalies in the right hand graphs. The location of each region can be found in Fig. 1. The range of results (indicated by the minimum and maximum error bars) represents the variability in model climate caused by the use of a suite of lapse rates to downscale the climate onto the glacier surface (this is explained in Allen et al, 2007a). Note the axes on the temperature anomaly graphs have been inverted, the diagonal line is the 1:1 line; any data point plotting above the 1:1 line indicates the glacial-geological temperature anomaly is larger than the HadCM3 temperature anomaly for that region and vice versa for data points plotting below the 1:1 line.

Positive precipitation correction factors are required for the glacier-climate model to offset the higher summer ablation caused by the relatively small temperature anomalies. For example, in the Pyrenees a correction factor in excess of $500 \mathrm{~mm}$ per month was required to achieve steady state mass balance conditions. These correction factors produce extreme climatic conditions over the model glacier surfaces; total annual precipitation is higher than LGM precipitation calculations from any other dataset, ELA climates are incompatible with measured climates over present day glaciers (Kotlyakov and Krenke, 1982; Leonard, 1989; Ohmura et al., 1992). These results indicate that differences between glacial-geological and HadCM3 LGM glacier calculations cannot be predominantly explained by the precipitation signal and, therefore, must reflect the discrepancy in the calculated LGM temperature signal.

\subsection{HadCM3 absolute $0 \mathrm{k}$ and $21 \mathrm{k}$ climates}

GCM climate anomalies are derived from the simulations of the two defined time periods and will inherently reflect any discrepancies in these absolute climates. For example, if the $21 \mathrm{k}$ climate was correct but the $0 \mathrm{k}$ climate was too cold LGM temperature anomalies would be underestimated. Using the glacier-climate model (Allen et al., 2007a), World Glacier Inventory (WGI) (National Snow and Ice Data Center, 1999) dataset of present day glaciers, and LGM glacialgeological evidence (Ehlers and Gibbard, 2004) it is possible to test the compatibility of HadCM3 (or other GCMs) $0 \mathrm{k}$ and $211 \mathrm{k}$ absolute climates with the cryosphere of these different time periods. The $0 \mathrm{k}$ and $21 \mathrm{k}$ climates were assessed by using the extrapolated climate (described in Sect. 3) to drive the glacier-climate model. The predictions of present day glaciers in Europe made by the mass balance model driven by the $0 \mathrm{k}$ climate were assessed against the WGI data using the method of Allen et al. (2007a). LGM glaciers calculated 
Table 2. Summary of the discrepancies between HadCM3 and "corrected" HadCM3 temperature anomalies and temperature anomalies reconstructed from glacial-geological evidence by Allen et al. (2007b). The discrepancy is calculated as HadCM3 temperature anomaly (original or corrected) - glacial-geological temperature anomaly North of Alps-Pyrenees includes all sites north of the Alps-Pyrenees line and between $4^{\circ} \mathrm{W}$ to $17^{\circ} \mathrm{E}$, the Mediterranean Basin includes all sites south of the Alps-Pyrenees line and between $4^{\circ} \mathrm{W}$ to $17^{\circ} \mathrm{E}$, Eastern Europe includes all sites between $35^{\circ} \mathrm{N}$ to $48^{\circ} \mathrm{N}$ and $17^{\circ} \mathrm{E}$ to $30^{\circ} \mathrm{E}$, Eastern Black Sea includes all sites between $35^{\circ} \mathrm{N}$ to $48^{\circ} \mathrm{N}$ and $30^{\circ} \mathrm{E}$ to $50^{\circ} \mathrm{E}$. The range is one standard deviation.

\begin{tabular}{lll}
\hline Region & $\begin{array}{l}\text { Original } \\
\text { Discrepancy }\left({ }^{\circ} \mathrm{C}\right)\end{array}$ & $\begin{array}{l}\text { Corrected } \\
\text { Discrepancy }\left({ }^{\circ} \mathrm{C}\right)\end{array}$ \\
\hline $\begin{array}{l}\text { North of the } \\
\text { Alps-Pyrenees }\end{array}$ & $6.7 \pm 1.8$ & $-0.1 \pm 1.9$ \\
$\begin{array}{l}\text { Mediterranean } \\
\text { Basin }\end{array}$ & $5.9 \pm 0.9$ & $0.2 \pm 1.1$ \\
$\begin{array}{l}\text { Eastern Europe } \\
\text { Eastern Black Sea }\end{array}$ & $0.0 \pm 1.0$ & $-3.9 \pm 1.1$ \\
\hline
\end{tabular}

by the mass balance model driven by the $21 \mathrm{k}$ climate were compared to the glacial-geological evidence (Ehlers and Gibbard, 2004) in the same way as the HadCM3 LGM climate anomaly simulations described in Sect. 4.2.

HadCM $30 \mathrm{k}$ climate led to a distribution of present day glaciers in Europe that is comparable with the result achieved by Allen et al. (2007a) using the CRU2.0 climate dataset (New et al., 2002). Calculations of non-glacierized cells exceed $90 \%$ in the four modelled regions, and range from $45 \%$ to $85 \%$ for glacierized cells (Fig. 7). The reasons for the more limited calculation of glacierized cells are discussed in detail in Allen et al. (2007a). The style of glacierization that results from the HadCM $30 \mathrm{k}$ climate suggests that it reflects a colder European climate than the CRU2.0 dataset (New et al., 2002). In all regions (except the Caucasus Mountains) mean and maximum calculated within-cell glacial coverage is substantially greater than described by the WGI (National Snow and Ice Data Center, 1999) and calculated by the mass balance model using CRU2.0 climate data as input (Allen et al., 2007a) (Table 3). Moreover, modelled ELAs are lower than the mean WGI snowlines; for example, in the Alps HadCM3 $0 \mathrm{k}$ climate mean ELA calculations range from $31 \mathrm{~m}$ to $405 \mathrm{~m}$ lower than the WGI mean snowline. The interpretation of a cold HadCM $30 \mathrm{k}$ climate is supported by the mass balance model simulating glaciers in currently non-glacierized mountain ranges across Europe and Russia. Seven of the twenty-nine mountain regions glaciated during the LGM, and modelled by Allen et al. (2007b), contain WGI data describing present day glacierization (National Snow and Ice Data Center, 1999); in contrast HadCM3 0 k climate results in glaciers in eighteen of these regions. The mass balance
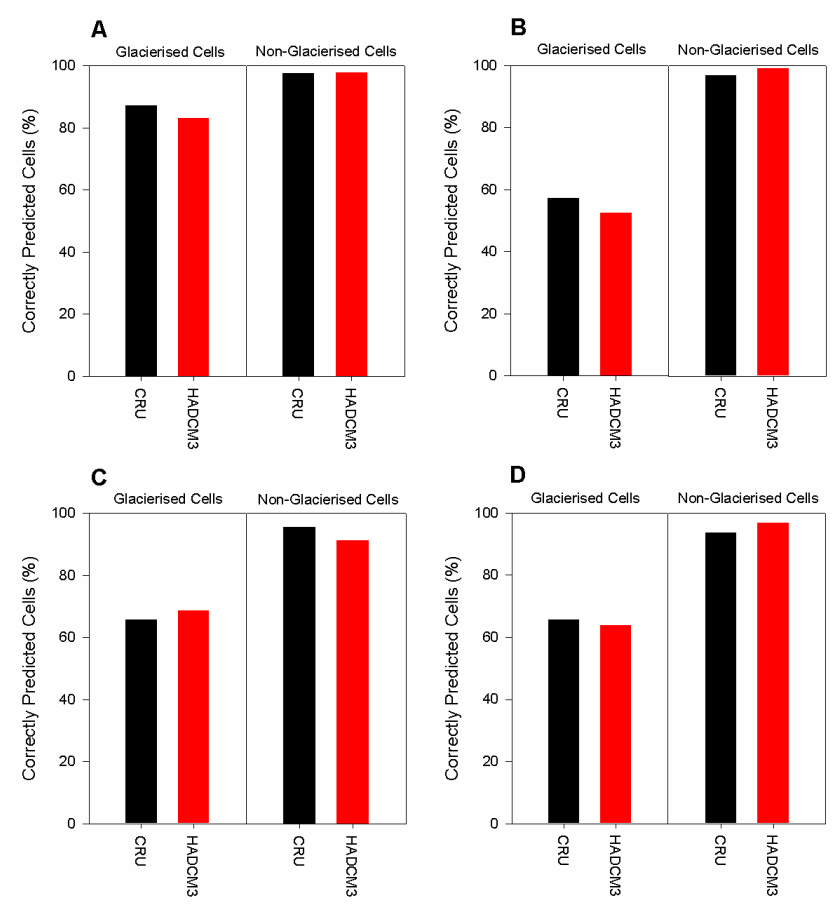

Fig. 7. Predictions of WGI (National Snow and Ice Data Center, 1999) glacierized and non-glacierized cells made by the CRU2.0 climate dataset (New et al., 2002) and HadCM3 $0 \mathrm{k}$ climate for the Alps (Graph A), Caucasus Mountains (Graph B), Southern Scandinavia (Graph C), and Northern Scandinavia (Graph D). Full details of the model domains used in these simulations are provided in Allen et al. (2007a).

model calculates a more extensive LGM glaciation when using HadCM3 absolute $21 \mathrm{k}$ climate, compared to HadCM3 LGM anomalies (applied to the CRU2.0 dataset). Steady state mass balance conditions are simulated in seven mountain regions and glaciation is modelled in 28 out of 29 regions in Europe and Eastern Black Sea (Fig. 8). In Russia mean AAR values, range from $0.2 \%$ to $6.7 \%$ across Northern Russia whilst the Southern Urals remain ice free (Fig. 8).

\subsection{Parameterisation of the glacier-climate model}

This simulation tested the assumption that the parameterisation of the glacier-climate model did not contribute to the discrepancy between glacial-geological and HadCM3 LGM climate anomalies. The glacier-climate model is described in full in Allen et al. (2007a) and is not repeated here. Melt factors (for snow and ice) used to calculate ablation (Allen et al., 2007a) and LGM glacier hypsometric profiles (Allen et al. 2007b) are likely to have the greatest effect on model results. Degree day factors are the most sensitive model variable and using the USGS "gtopo30 arcsec" DEM (USGS, 1996) meant that no explicit reconstruction of LGM ice depth was made. Temperature thresholds controlling the onset of ablation and proportionality of precipitation falling as rainfall 


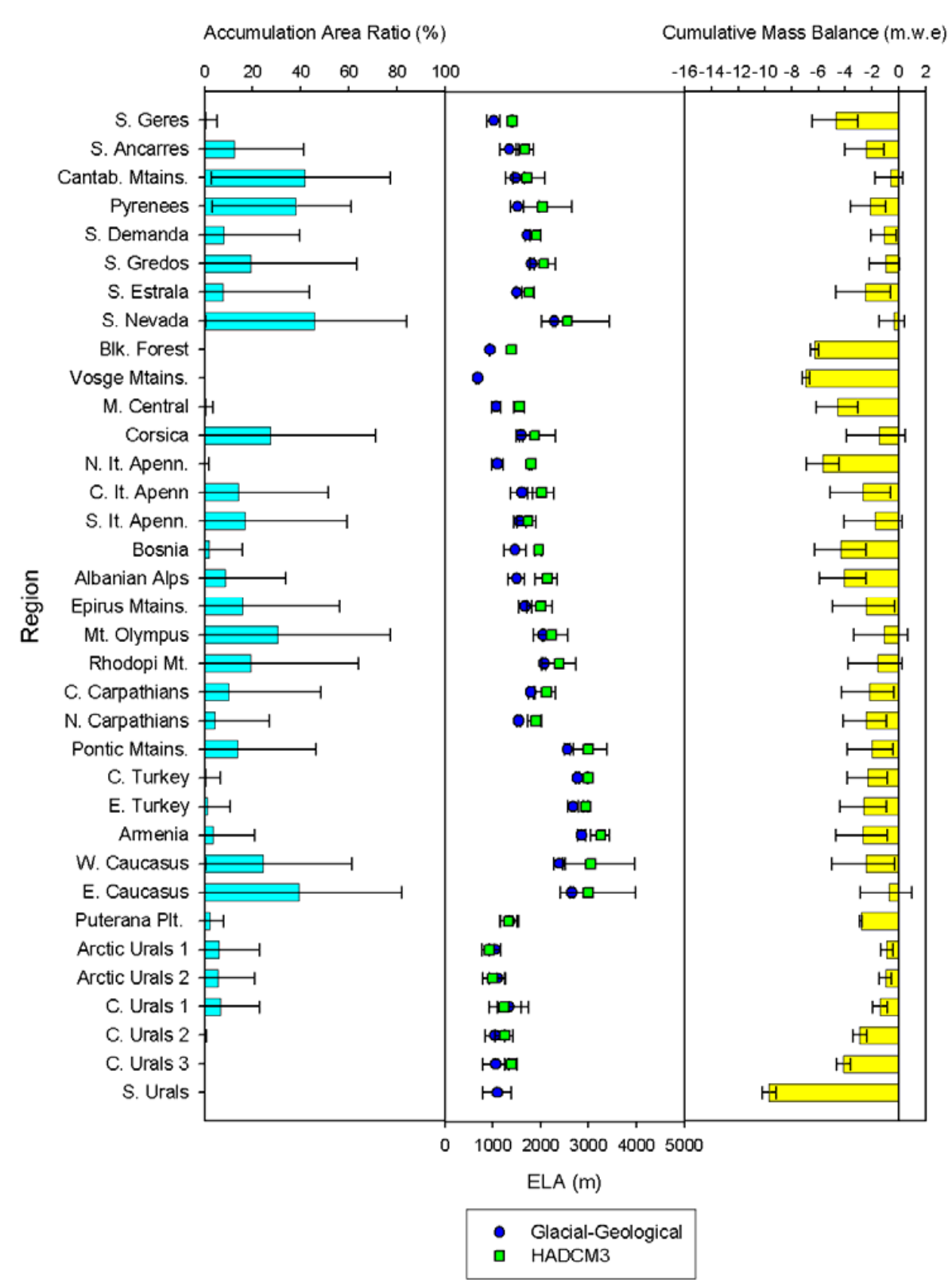

Fig. 8. HadCM3 $21 \mathrm{k}$ climate predictions of AAR, ELA, and cumulative mass balance for regions glaciated during the LGM (the location of regions can be found in Fig. 1). ELA calculations are plotted alongside the ELA estimates from Allen et al. (2007b) (labelled as glacialgeological). The range in results for each region (represented by minimum and maximum error bars) is caused by the suite of lapse rate combinations used to downscale the input climate onto the model glacier surface simulating different annual mass balance profiles and therefore different glaciological results.

or snowfall will only have a very limited influence on the results owing to their limited range of values and were not investigated. For this simulation it was assumed that the INQUA LGM glacier database (Ehlers and Gibbard, 2004a) and HadCM3 LGM climate anomalies were correct. Using these fixed boundary conditions, the degree day factors and hypsometric profile were adjusted using the iterative process (melt factors $0.1 \mathrm{~mm} /$ day $/{ }^{\circ} \mathrm{C}$ and hypsometric profile by $10 \mathrm{~m}$ per iteration) described in Sect. 5.1 until equilibrium surface mass balance conditions were simulated by HadCM3 LGM climate anomalies.

Optimised melt factors range from $0.1 \mathrm{~mm} /$ day $/{ }^{\circ} \mathrm{C}$ to $2 \mathrm{~mm} /$ day $/{ }^{\circ} \mathrm{C}$ for snow surfaces and $0.5 \mathrm{~mm} /$ day $/{ }^{\circ} \mathrm{C}$ to $3 \mathrm{~mm} /$ day $/{ }^{\circ} \mathrm{C}$ ice surfaces (Fig. 9). These values are lower than the lowest published melt factors for snow and ice of $\sim 3 \mathrm{~mm} /$ day $/{ }^{\circ} \mathrm{C}$ and $\sim 5 \mathrm{~mm} /$ day $/{ }^{\circ} \mathrm{C}$, respectively 
Table 3. Comparison of within-cell glacial coverage described by the WGI and calculated using the CRU2.0 climate dataset and HadCM3 $0 \mathrm{k}$ climate. Allen et al. (2007a) converted the WGI data describing glacier area into a grid format (at the resolution of the CRU2.0 dataset) compatible with the output of the glacier-climate model, the within cell glacial coverage is the percentage of glacier ice contained within each glacierized cell in this converted dataset. The glacier-climate model simulated the size of the accumulation area; the total area of the glacier (in brackets) was estimated using an AAR value of 0.67 which is a commonly used value for present day mountain glaciers (Benn and Evans, 1998)

\begin{tabular}{|c|c|c|c|c|c|c|c|c|}
\hline & \multicolumn{2}{|c|}{ The Alps } & \multicolumn{2}{|c|}{ Southern Scandinavia } & \multicolumn{2}{|c|}{ Northern Scandinavia } & \multicolumn{2}{|c|}{ Caucasus Mountains } \\
\hline & \multicolumn{8}{|c|}{ Within Cell Glacial Coverage (\%) } \\
\hline Model & Mean & Max & Mean & Max & Mean & Max & Mean & Max \\
\hline WGI & 6 & 77 & 7 & 55 & 4 & 67 & 6 & 35 \\
\hline CRU2.0 & $7(11)$ & $52(78)$ & $3(5)$ & $22(33)$ & $2(4)$ & $29(44)$ & $3(5)$ & $17(26)$ \\
\hline HadCM3 & $12(18)$ & $61(91)$ & $9(14)$ & $46(69)$ & $6(9)$ & $38(56)$ & $5(7)$ & $25(37)$ \\
\hline
\end{tabular}

(Braithwaite and Zhang, 2000). To achieve zero mass balance, model LGM glacier profiles had to be raised between $400 \mathrm{~m}$ and $900 \mathrm{~m}$ (Fig. 9), meaning that ELAs were significantly higher than those shown by Allen et al. (2007b) (Fig. 9).

\subsection{Discussion}

The correction factors derived from the simulation described in Sect. 5.1 support the conclusion that HadCM3 temperature anomalies themselves are the primary cause of the limited LGM glaciation calculated using HadCM3 LGM inputs. Precipitation correction factors are, in the main, so large that model LGM climates become implausible, whilst the majority of "corrected" temperature anomalies are in closer agreement with glacial-geological temperature anomalies. This provides increased confidence in the size of LGM temperature anomalies reconstructed from the CRU2.0 climate dataset (New et al., 2002) and suggests that LGM annual temperature anomalies are larger than the original HadCM3 estimates.

HadCM3 $0 \mathrm{k}$ climate yielded, via the mass balance model, a more extensive present day glacierization in the Alps, Scandinavia and Caucasus Mountains than is described in WGI dataset (National Snow and Ice Data Center, 1999) as well as glacierization in many currently non-glaciated mountain regions. This suite of results would suggest that the $0 \mathrm{k}$ simulation produces a European climate that is colder than the actual present day climate. The $21 \mathrm{k}$ absolute climate allowed the mass balance model to simulate steady state conditions in 7 of the 29 modelled regions in Europe but the over riding trend is still an under-calculation of the extent of LGM glaciers compared to the glacial-geological evidence. This would suggest that the $21 \mathrm{k}$ simulation produces a European climate that is too warm.

Optimising the glacier-climate model parameter set demonstrated that the modelling approach was not preventing HadCM3 LGM climate estimates from simulating steady-state glacier conditions, therefore, the discrepancy comes from an incompatibility between the LGM glacialgeological record and HadCM3 LGM climate anomalies. Allen et al. (2007b) discussed in detail the current limitations of the European LGM glacial-geological evidence contributing to the INQUA glacier database (Ehlers and Gibbard, 2004). The lack of a reliable chronology meant that it is likely some of the glacier profiles pre-date the LGM, and the available evidence suggests that some pre-LGM glaciers were larger. It is acknowledged that the over-calculation of LGM glacier extents will exacerbate the difference between the reconstructions using glacial-geological evidence (Ehlers and Gibbard, 2004; Allen et al., 2007b) and the LGM conditions modelled by HadCM3. However, it is not considered the principal cause of the discrepancy for two reasons. First, recent studies dating glacial-geological evidence (e.g Sanchez and Arquer, 2002; García-Ruiz et al., 2003; Woodward et al., 2004; Hughes and Woodward, 2008) propose changes to the extent of LGM glaciers rather than concluding the region was not glaciated. For example, the chronology of the Lourdes Valley, Northern Pyrenees established by Herail et al. (1986) places the terminus of the LGM glacier $10 \mathrm{~km}$ to $15 \mathrm{~km}$ behind the terminus of the maximum glacial advance. Second, in regions where glacial-geological evidence has been reliably dated and constrained to the LGM (e.g. Vosges Mountains) (Dricot et al., 1991) there is no discernable improvement in agreement between the glacial-geological or HadCM3 climate reconstructions.

\section{Conclusions}

Our understanding of future climate change is, and will be, based on inferred processes and forecasts from complex atmospheric GCMs. Confidence in GCM results, and indeed validation of the models, can be gained by testing them against known past conditions. The LGM is perhaps the best opportunity for such inspection, as it is a substantial episode 


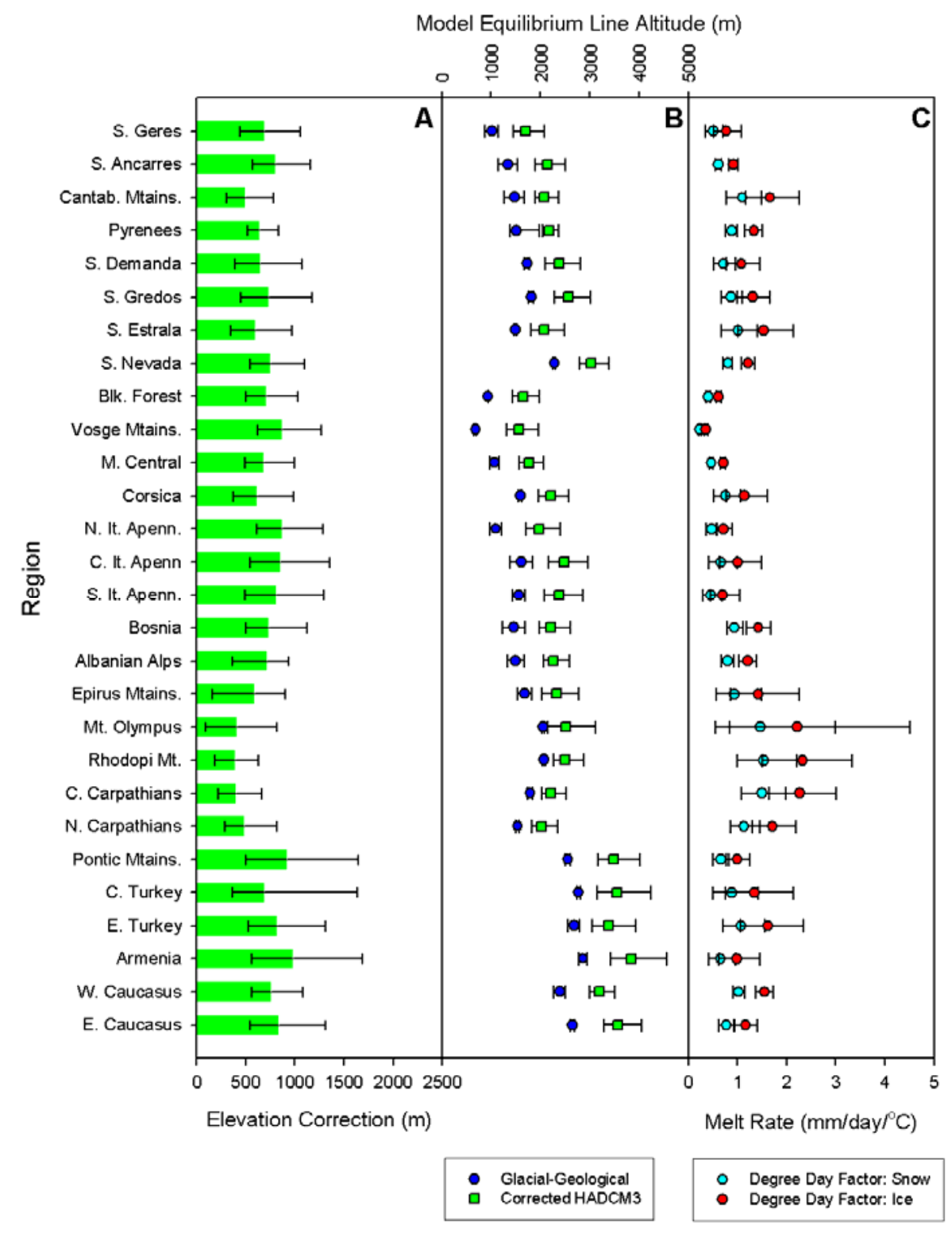

Fig. 9. Optimised elevation (Graph A) (with the adjusted ELA; Graph B) and adjusted degree day factors melt factors (Graph C) required for the HadCM3 LGM climate anomalies to simulate equilibrium surface mass balance over the LGM glacier profiles of Europe and Eastern Black Sea reconstructed from glacial-geological evidence (Ehlers and Gibbard, 2004). The ELA reconstructions of Allen et al. (2007b) have are included in Graph B for comparison purposes. Locations of the glaciated regions are shown in Fig. 1. The range in results for each region (represented by minimum and maximum error bars) is caused by the suite of lapse rate combinations used to downscale the input climate onto the model glacier surface simulating different annual mass balance profiles and therefore different glaciological results.

of climate change yet is recent enough for the bulk geography of the planet to be largely unchanged (e.g. the position of the oceans and landmasses). Hence, GCM models should be capable of calculating the size and distribution of glaciers at the LGM if they are sufficiently advanced so as to predict future climate.

The glacial history of Europe, concentrating on small valley glaciers, presents an excellent case study in which to test the competence of GCM output. Simple glacier models can inform us about the climate needed for ice to exist in steadystate form (Allen et al., 2007a) and, hence, climate parameters for several sites in Europe at the LGM can be established (Allen et al. 2007b). Such work can be used to examine GCM output in two ways: first, through direct comparison of the GCM and glacier model results, and second by using GCM outputs as an input to the glacier model to calculate the extent of ice. 
HadCM3 LGM climate anomalies are consistently smaller than those determined by glacier-climate modelling of regions of well described glaciation in Europe (Ehlers and Gibbard, 2004a). The same is probably true of many GCM outputs. This under-calculation appears to be a result of modernday climates being too cold (over representation of present day glaciers) and LGM conditions being too warm (under representation of glacial extent).

While it is difficult to speculate about previously published reasons for GCM shortcomings based on the glacier-climate model results, as results of only one GCM comparison analysis have been presented, this paper demonstrates a simple method of testing future $0 \mathrm{k}$ and $21 \mathrm{k} \mathrm{GCM}$ simulations which could be used in assessing either a large suite of GCM results, such as the PMIP2 suite of models, or testing the sensitivity of climate processes within an individual model.

This paper, in conjunction with Allen (2007a, b), shows it is now possible to utilise former glaciers to test and validate climate models. The results presented here are only the first attempt at such work, however. There are several ways in which this work can be expended and enhanced, including accounting for seasonality and developing sophistication in the mass balance model (possibly using a full energy balance model). The constraint of such work comes with the accuracy of palaeo-glacier data and in particular the dating of glacial maxima. A reliable Europe-wide chronology of glacier advances would allow this research to offer important insights into the time-dependent modification of climate, rather than an assumed snapshot.

\section{Appendix A}

\begin{tabular}{|c|c|}
\hline AAR & Accumulation Area Ratio \\
\hline CRU & $\begin{array}{l}\text { Climate Research Unit - University of } \\
\text { East Anglia }\end{array}$ \\
\hline ELA & Equilibrium Line Altitude \\
\hline GCM & General Circulation Model \\
\hline HadCM3 & Hadley Centre Climate Model - version 3 \\
\hline INQUA & International Quaternary Association \\
\hline LGM & Last Glacial Maximum \\
\hline PFT & Plant Functional Type \\
\hline \multirow[t]{2}{*}{ PMIP } & Palaeoclimate Modelling \\
\hline & Intercomparison Project \\
\hline WGI & World Glacier Inventory \\
\hline USGS & United States Geological Service \\
\hline
\end{tabular}

Acknowledgements. This work was funded by a NERC studentship. We thank M. Sanchez Goñi, an anonymous referee, and the editor Marie-France Loutre, for helpful and constructive advice. Robert Allen would like to thank Martin Siegert and Tony Payne for their support and advice during the period of this research.

M.-F. Loutre

\section{References}

Allen, R. J.: Reconstructing the Last Glacial Maximum Climate of Europe and Russia using the Glacial-Geological Record, PhD Thesis, School of Geographical Sciences, University of Bristol, 304 pp., 2006.

Allen, R. J., Siegert, M. J. and Payne, T.: Reconstructing glacierbased climates of LGM Europe and Russia I: numerical modelling and validation methods, Clim. Past Discuss., 3, 11331166, 2007a, http://www.clim-past-discuss.net/3/1133/2007/.

Allen, R. J., Siegert M. J., and Payne, T.: Reconstructing glacierbased climates of LGM Europe and Russia II: A dataset of LGM precipitation/temperature relations derived from degreeday modelling of palaeo glaciers, Clim. Past Discuss., 3, 11671198, 2007b, http://www.clim-past-discuss.net/3/1167/2007/.

Berger, A. and Loutre, M.F.: Insolation values for the climate of the last 10 million years, Quatern. Sci. Rev., 10, 291-317, 1991.

Braithwaite, R. J. and Zhang, Y.: Sensitivity of mass balance of five Swiss glaciers to temperature changes assessed by tuning a degree day model, J. Glaciol., 46, 7-14, 2000.

Cowling, S. A. and Sykes, M. T.: Physiological significance of low atmospheric $\mathrm{CO}_{2}$ for plant-climate interactions, Quatern, Res., 52, 237-242, 1999.

Dricot, E., Pétillon, M., and Seret, G.: When and why did glaciers grow or melt in the Vosges Mountains (France)?, in: Klimageschichtliche Probleme der letzten 130000 Jahre, edited by: Frenzel, B., 363-376, Palaöklimaforschung, Gustav Fischer Verlag, Stuttgart, 1991.

Ehlers, J. and Gibbard, P. L.: Quaternary Glaciations - Extent and Chronology, Part 1: Europe, in: Developments in Quaternary Science 2, edited by: Rose, J., Elsevier, London, 488 pp., 2004.

Fairbanks, R. G., Mortlock, R. A., Chiu, T.-C., Cao, L., Kaplan, A., Guilderson, T. P., Fairbanks, T. W., Bloom, A. L., Grootes, P. M., and Nadeau, M.-J.: Radiocarbon calibration curves spanning 0 to $50000 \mathrm{yr}$ BP based on paired ${ }^{230 T h} /{ }^{234} \mathrm{U} /{ }^{238} \mathrm{U}$ and ${ }^{14} \mathrm{C}$ dates on pristine corals, Quatern. Sci. Rev., 24, 1781-1796, 2005.

Farerra, I., Harrison, S. P., Prentice, I. C., Ramstein, G., Guiot, J., Bartlein, P. J., Bonnefille, R., Bush, M., Cramer, W., von Grafenstein, U., Holmgren, K., Hooghiemstra, H., Hope, G., Jolly, D., Lauritzen S.-E., Ono, Y., Pinot, S., Stute, M., and Yu, G.: Tropical climates at the Last Glacial Maximum: a new synthesis of terrestrial palaeoclimate data. 1. Vegetation, lake-levels and geochemistry, Clim. Dynam., 15, 823-856, 1999.

García-Ruiz, J. M., Valero-Garcés, B. L., Martí-Bono, C., and González-Sampériz, P.: Asynchroneity of maximum glacier advances in the central Spanish Pyrenees, J. Quatern. Sci., 18, 61$72,2003$.

Gordon, C., Cooper, C., Senior, C. A., Banks, H., Gregory, J. M., Johns, T. C., Mitchell, J. F. B., and Wood, R. A.: The simulation of SST, sea ice extents and ocean heat transports in a version of the Hadley Centre coupled model without flux adjustments, Clim. Dynam., 16, 147-168, 2000.

Harrison, S. P.: Contributing to global change science: the ethics, obligations and opportunities of working with palaeoenvironmental databases. Norsk Geografisk Tidsskrift-Norwegian Journal of Geography, 57, 1-8. 2003.

Harrison, S. P. and Prentice, I. C.: Climate and $\mathrm{CO}_{2}$ controls on global vegetation distribution at the last glacial maximum: analy- 
sis based on palaeovegetation data, biome modelling and palaeoclimate simulations, Glob. Change Biol., 9, 983-1004, 2003.

Herail, G., Hubschman, J., and Jalut, G.: Quaternary glaciations in the French Pyrenees, Quatern. Sci. Rev., 5, 397-402, 1986.

Hoar, M. R., Palutikof, J. P., and Thorne, M. C.: Model intercomparison for the present day, the mid-Holocene, and the Last Glacial Maximum over western Europe. J. Geophys. Res., 109, D08104, doi:10.1029/2003JD004161, 2004.

Hughes, P. D. and Woodward, J. C. Timing of glaciation in the Mediterranean mountains during the last cold stage, J. Quatern. Sci., 23(6-7) 575-588, 2008.

Jost, A., Lunt, D., Kageyama, M., Abe-Ouchi, A., Peyron, O., Valdez, P. J., and Ramstein, G.: High-resolution simulations of the last glacial maximum climate over Europe: a solution to discrepancies with continental palaeoclimatic reconstructions?, Clim. Dynam., 24, 577-590, 2005.

Joussame, S. and Taylor, K. E.: Status of the Paleoclimate Modelling Intercomparison Project (PMIP), in: Proceedings of the first international AMIP scientific conference, Monterrey, California, USA, 15-19 May, WRCP-92, 425-430, 1995.

Kageyama, M., Peyron, O., Pinot, S., Tarasov, P., Guiot, J., Joussaume, S., and Ramstein, G.: The Last Glacial Maximum climate over Europe and western Siberia: a PMIP comparison between models and data. Clim. Dynam., 17, 23-43, 2001.

Kageyama, M., Harrison, S. P., and Abe-Ouchi, A.: The depression of tropical snowlines at the last glacial maximum: What can we learn from climate model experiments?, Quatern. Int., 138-139, 202-219, 2005

Kislov, A. V., Tarasov, P. E., and Sourkova, G. V.: Pollen and other proxy-based reconstructions and PMIP Simulations of the Last Glacial Maximum mean annual temperature: an attempt to harmonize the data-model comparison procedure, Acta Palaeontologica Sinica, 41, 539-545, 2002.

Kohfeld, K. E. and Harrison, S. P.: How well can we simulate past climates? Evaluating the models using global palaeoenvironmental datasets, Quatern. Sci. Rev., 19, 321-346, 2000.

Kotlyakov, V. M. and Krenke, A. N.: Investigations of the hydrological conditions of alpine regions by glaciological methods, International Association of Hydrological Science Publications, 138, 31-42, 1982.

Leonard, E. M.: Climatic change in the Colorado Rocky Mountains: estimates based on the modern climates at Late Pleistocene equilibrium lines, Arctic Alpine Res., 21, 245-255, 1989.

Mark, B. G., Harrison, S. P., Spessa, A., New, M., Evans, D. J. A., and Helmens, K. F.: Tropical snowlines changes at the last glacial maximum: A global assessment, Quatern. Int., 138-139, 168-201, 2005.

National Snow and Ice Data Center: World Glacier Inventory, World Glacier Monitoring Service and National Snow and Ice Data Center/World Data Center for Glaciology, Boulder, CO, USA, Digital Media, 1999.

New, M., Lister, D., Hulme, M. and Makin, I.: A high-resolution data set of surface climate over global land areas, Climate Res., $21,1-25,2002$

Ohmura, A., Kasser, P., and Funk, M.: Climate at the equilibrium line of glaciers. J. Glaciol., 38(130), 397-411, 1992.
Owen, L. A. and Benn, D. I.: Equilibrium-line altitudes of the Last Glacial Maximum for the Himalaya and Tibet: an assessment and evaluation of results, Quatern. Int., 138-139, 55-78, 2005.

Peltier, W. R.: Global Glacial Isostasy and the Surface of the IceAge Earth: The ICE-5G(VM2) model and GRACE, Annu. Rev. Earth Pl. Sc., 32, 111-149, 2004.

Peyron, O., Guiot, J., Cheddadi, R., Tarasov, P., Reille, M., de Beaulieu, J,-L., Bottema, S., and Andrieu, V.: Climatic reconstruction in Europe for $18000 \mathrm{yr}$ BP from pollen data, Quatern. Res., 49, 183-196, 1998.

Pollard, D. and PMIP Participating Groups: Comparisons of ice-sheets surface mass budgets from the Paleoclimate Modeling Intercomparison Project (PMIP) simulations, Global Planet. Change, 24, 79-106, 2000.

Pope, V. D., Gallani, M. L., Rowntree, P. R., and Stratton, R. A.: The impact of a new physical parameterizations in the Hadley Centre climate model - HadAM3, Clim. Dynam., 16, 123-146, 2000.

Porter, S. C.: Present and past glaciation threshold in the Cascade Range, Washington, USA.: Topographic and climatic controls and paleoclimatic implications, J. Glaciol., 18, 101-116, 1977.

Prentice, I. C., Guiot, J., Huntley, B., Jolly, D., and Cheddadi, R.: Reconstructing biomes from palaeoecological data: A general method and its application to European pollen data at $0 \mathrm{k}$ and 6 ka, Clim. Dynam., 12, 185-194, 1996.

Prentice, I. C., Cramer, W., Harrison, S. P., Leemans, R., Monserud, R. A., and Solomon, A. M.: A global biome model based on plant physiology and dominance, soil properties, and climate, J. Biogeogr., 19, 117-134, 1992.

Sanchez, M. F. and Arquer, P. F.: New radiometric and geomorphological evidences of a last glacial maximum older than $18 \mathrm{ka}$ in SW European mountains: the example of Redes National Park (Cantabrian Mountains, NW Spain), Geodin. Acta, 15, 93-101, 2002.

Tarasov, P. E., Peyron, O., Guiot, J., Brewer, S., Volkova, V. S. Bezusko, L. G., Dorofeyuk, N. I., Kvavadze, E. V., Osipova, I. M., and Panova, N. K.: Last Glacial Maximum climate of the former Soviet Union and Mongolia reconstructed from pollen and plant macrofossil data. Clim. Dynam., 15, 227-240, 1999.

Tarasov, P. E., Volkova, V. S., Webb III, T., Guiot, J., Andreev, A. A., Bezusko, L. G., Bezusko, T. V., Bykova G. V, Dorofeyuk, N. I., Kvavadze, E. V., Osipova, I. M., Panova, N. K., and Sevastyanov, D. V.: Last Glacial Maximum biomes reconstructed from pollen and plant macrofossil data from northern Eurasia, J. Biogeogr., 27, 609-620, 2000.

Turon, J.-L., Lézine, A.-M., and Denèfle, M.: Land-sea correlations for the last glaciation inferred from a pollen and dinocyst record from the Portuguese margin, Quatern. Res., 59, 88-96, 2003.

USGS (United States Geological Service): http://edcdaac.usgs.gov/ gtopo30/gtopo30.html, last access on 15 September 2007, 1996.

Woodward, J. C., Macklin, M. G., and Smith, G. R.: Pleistocene glaciation in the mountains of Greece, in: Quaternary Glaciations - Extent and Chronology Part I: Europe, edited by: Ehlers, J. and Gibbard, P. L., 155-174, 2004. 